\title{
VI. On the real origin of that resin known under the name of sandarac, and that of Gum Arabic
}

\section{Schousboe}

To cite this article: M. Schousboe (1799) VI. On the real origin of that resin known under the name of sandarac, and that of Gum Arabic , Philosophical Magazine Series 1, 5:19, 239-242, DOI: $10.1080 / 14786449908677147$

To link to this article: http://dx.doi.org/10.1080/14786449908677147

曲 Published online: 18 May 2009.

Submit your article to this journal $\sqsubset$

Џll Article views: 3

Q View related articles ๘ 
Let the firt variety of filiceous ores be fuppofed to contain, flex 12 , clay 8 , lime $5-25$.

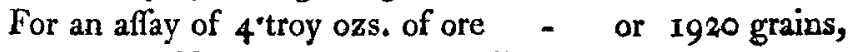

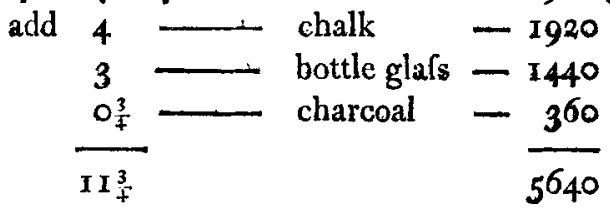

And, laftly, let the fecond variety of this genus of ironftone be fuppofed to contain, filex 10 , lime 7 , clay $5=22$.

To 4 troy ounces of the ore - or 1920 grains,

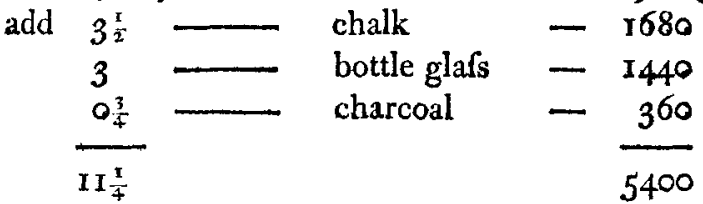

Clafs of equalifed mixtures, compofed of, clay 7 , lime 7 , filex $\eta=2$.

To aflay of this ore 4 troy ounces

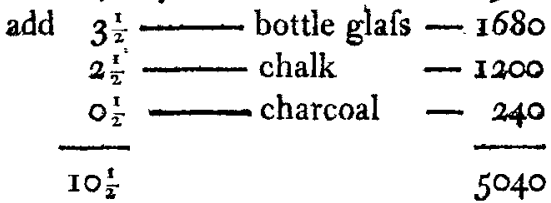

VI. On the real Origin of that Refin known under the Name of Sandarac, and that of Gum Arabic. By M. Scuous$B O E *$.

\section{O}

JUM Sandarac is an article of trade brought from the fouthern provinces of the kingdom of Morocco. About $\mathrm{fix}$ or feven hundred quintals of it are exported every year from Santa Cruz, Mogador, and Saffy. In the language of the country it is called $E l$ graffa. The tree which produces it is a Thuia, found alfo by $\mathrm{M} . \mathrm{Vahl}$ in the kingdom of

- From a Danilh Journal, entitled, The Pby/ical, Medical, and Ecoromical Library, Part III. 1799.

Tunis. 
Tunis*. It was made known feveral years ago by Dr. Shaw, who named it, Cypreffus fructu quadrivalvi, Equifeti inflar articulatis; but neither of thefe learned men was acquainted with the economical ufe of this tree; probably becaufe, being not common in the northern part of Barbary, the inhabitants find little advantage in collecting the refin which exudes from it. This refin hitherto has been afcribed to the Juniperus communis, Juniperus Lycia, or the Cedar of Lebanon, without reflecting that the Juniperus communis does not grow in Africa, and Sandarac feems to belong exclufively to that part of the world. M. Schourboe, who faw the fpecies of Tbuia in queftion, fays that it does not rife to more than the height of twenty or thirty feet at moft, and that the diameter of its trunk does not exceed ten or twelve inches. It diftinguifhes itfelf, on the firft view, from the two other fpecies of the fame genus, cultivated in gardens, by having a very diftinct trunk, and the figure of a real tree; whereas in the latter the branches rife from the root, which gives them the appearance rather of buines. Its branches alfo are more articulated and brittle. Its fowers, which are not very apparent, thew themfelves in April; and the fruit, which are of a fpherical form, ripen in September. When a branch of this tree is held to the light, it appears to be interfperfed with a multitude of tranfparent veficles which contain the refin. When thefe veficles burft in the fummer months, a refinous juice exudes from the trunk and branches, as is the cafe in other coniferous trees. This refin is the Sandarac, which is collected by the inhabitants of the country, and carried to the ports, from which it is tranfported to Europe. It is employed in making fome kinds of fealingwax, and in different forts of varnith. In 1793 a hundred weight of it coft in Morocco from 13 to $13 \frac{x}{2}$ piaftres, which make about $3 l .5 s$. to $3 l .7 s$. and $6 d$. fterling. The duty on exportation was about $7 s .6 d$. fterling per quintal.

Sandarac, to be good, muft be of a bright-yellow colour, pure and tranfparent. It is an article very difficult to be

* A complete defcription of it, with a good figure, may be found in his work entitled, Synbol. Botan. Part II. p. 96. Plate XLVII. under the name Thuia articulata. 
adulterated. Care, however, mult be taken that the Moors do not mix with it too much fand. It is probable that a tree of the fame kind produces the gum fandarac of Senegal, which is exported in pretty confiderable quantities.

Another article of commerce in which the kingdom of Morocco participates with Senegal, is that gum called Gum Arabic, known by the name of Al leilk. The tree which produces it grows only in the fouthern provinces of that ftate. The quantity of this article exported to the different parts of Europe from the ports of Morocco may amount to about eight or nine quintals. M. Schoufboe fays, that this tree is the Mimofa nilotica, named in the country $A l$ tblab; but this is no reafon why the fame kind of gum fhould not be collected in the more fouthern countries of Africa from the Mimofa Senegal, and even from other trees of the fame fpecies, as we are told by various authors. In Barbary the people make a difference between the gum of Senegal and that of the country. The former is preferred on account of its purity, whitenefs, and tranfparency, which in general are the properties fought for in this article.

The gum which I collected myfelf in the province of Mogador, fays M. Schouboe, exudes from the trunk and branches of the tree, in the fame manner as that of our fruit-trees. It is in round lumps, of the fize of a hazle-nut, or rather that of a walnut. Thefe lumps, indeed, by becoming united to each other, form maffes fometimes of the fize of the fift, or even of the head; but this only happens in confequence of the adhefion which takes place between the pieces of gum, when ftill frefh, after they have been detached from the tree, and chiefly at that part which was attached to the bark, where the refinous juice has not had time to harden. If earth, fmall ftones, and other foreign bodies, are fometimes found in thefe maffes, it arifes from fraud; and M. Schoufoe fufpects that this circumftance has given rife to the opinion of the gum being found at the bottom of the tree, and that it exudes from the roots, which, as he thinks, is void of foundation. Were this the cafe, it appears to him that, befides the earth and fand with which the gum is accidentally dirtied, balls of thefe matters ought to be found Vox. V. 
in the infide, and even fo mixed with the mucilaginous fubftance that it would be imporible ever to purify it completely; while, on the other hand, the gum wlich comes from Senegal is fill purer than that of Barbary.

M. Schounboe, however, oblerves, that the fandarac and gum exported from the port of Saffy have a brown or reddin colour; but he afcribes this colour to the quantity of the red oxyd of iron mixed with the foil of the province of Abda, where this port is fituated. This oxyd conmunicates its colour even to the whi eft wool; and the inbabitants of that province may be diftinguifhed by the reddifh tint of their clothes, which cannot be cntirely defiroycd by any procefs. In the months of July and Angutt, when heavy dews fall, the gum lofes a great dal of its tranfparency, as well as of its other good qualities. A hundred weight of this fubftance coft at Mogador, in 1793 , about $2 l$. fterling, without including about $4 \mathrm{~s}$. cuftom-houfe duty. The gum does not appear to be employed by the inbabitants of Morocco for any purpofe whatever: the whole of what they collect is fold to the different commercial nations of Europe.

VII. On tbe Peflilential Difeafes wbicb, at diffirent times, apprared in the Atbenian, Cartbaginian and Roman Armies, in the Neigbbourbood of Sirraiaja. By the late E. H. SM гтI, Physian*.

\section{SECTIOX T.}

SYRACUSE, the moft beantiful of all the cities built by the Greeks, was founded by Archias, a Corinthian, of the race of Hercules*. He firft expelled the natives from Ortygia, where he commenced the city, which was afterwards extended to the neighbouring continent. This place, fo celebrated in ancient hiftory, the birth-place of Archimedes, and theatre of many memorable tranfactions, now reduced to a miferable town, of inferior confequence even in Sicily, is fituated in north latitude $37^{\circ} \cdot 5^{\prime}$, a little above Cape Paffara

* Froin the American Mctical Repuffitory, Vol. II. No. 4.

+ Cicero in Ver. Aet. IL. Lib. iv. O̧ 117 . Thucydides, B. vi. 